\title{
Fundamental Study on Reaction Rate in the Chemical Humidity Control System
}

○学 岡野 僚太 (広島大工院) 正 松村 幸彦 (広島大工) 正 菊地 義弘 (広島大工)

正 北原 博幸 (トータルシステム研究所)

Ryota OKANO, Yukihiko MATSUMURA, Yoshihiro KIKUCHI

Hiroshima University, 1-4-1 Kagamiyama HigashiHiroshima-shi,Hiroshima

Hiroyuki KITAHARA, Total System Laboratory

Key Words : Chemical Humidity Control System, Dehumidification

\section{1. 緒言}

近年空調の省エネルギ一化を図るため除湿の高効率化 が求められるようになっている。従来の空調システムに おいては空気を露点以下まで领却し結露させることで除 湿を行うため過度の冷却を必要とし、空調の効率低下を 招いている。我々は除湿剂を用いることで空気を過度に 冷却することなく十分に除湿でき、かつ凝縮器排熱を利 用して除湿剂を脱水するケミカル調湿システムを提案し た。除湿剤のスクリーニングを行った結果、炭酸ナトリ ウム 1 水和塩の水和による炭酸ナトリウム 10 水和塩の生 成反応を選択した ${ }^{11}$ 。

このシステムにおいては、空調の室内機において 1 水 和塩による空気の除湿を行い、精製した 10 水和塩を室外 機の排熱で再生させる。このときに，室内機と室外機の間 で連続的に水和塩を移動させる必要がある。そこで、我々 は炭酸ナトリウム水和塩を不活性溶媒に縣溜させたスラ リーを利用することを検討している。我々の提案するシ ステム実現のためには水和塩の吸水之脱水過程の反応特 性を検討する必要があり、ここで対象とするシステムに おいては、炭酸ナトリウム 1 水和塩スラリーの吸湿特性 に関する知見が必要である。同様のスラリーについては、 ケミカルヒートポンプの炭酸ナトリウム 10 水和塩の脱 水過程において不活性溶媒を添加することで充填層の伝 熱特性向上を図る検討例がある2)。しかしながら、水和 反応についての定量的な速度論的検討は行われていない。 そこで本研究では、溶媒中での炭酸ナトリウム 1 水和塩 の吸水速度を測定し、吸湿システムの性能の推算に必要 な知見を得ることを目的とする。

\section{2. $\mathrm{PEG}$ - 水系の平衡水蒸気圧の決定}

炭酸ナトリウム 1 水和塩が吸湿して 10 水和塩となる条 件は，周囲の水蒸気圧が水和塩の平衡水蒸気圧より大き いことである。さらに、不活性溶媒スラリーを用いる場 合には、この平衡蒸気圧に相当する不活性溶媒の含水量 よりも高い含水量の時に水和が進行する。このため、用い る溶媒と水の平衡水上気圧を知ることは重要である。

本研究では不活性溶媒として PEG を選択し、PEG と 水の混合物系の蒸気圧を実験により求めた。実験装置を Fig. 1 に示す。反応器は三角フラスコであり、ここに水分

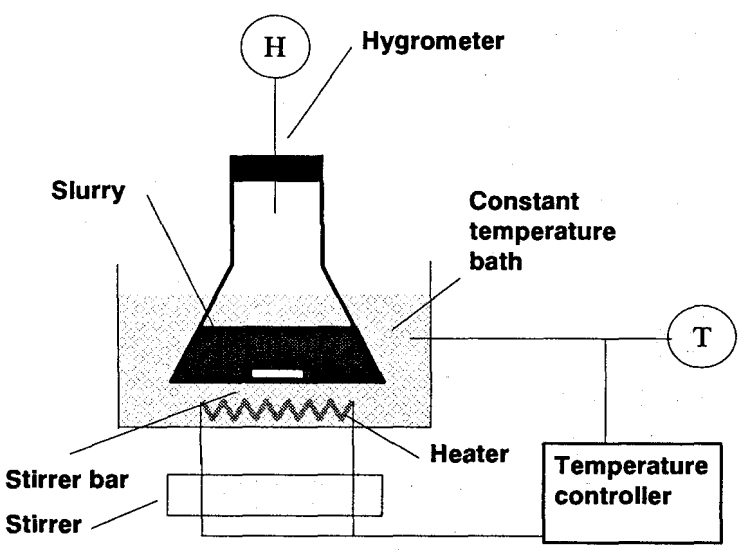

Fig.1 Experimental apparatus.

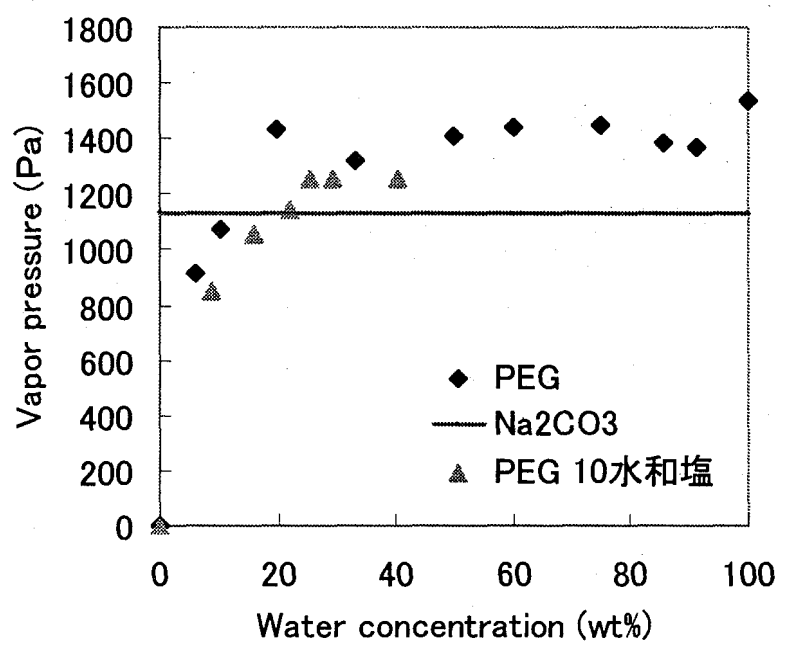

Fig.2 Water vapor pressures of water-PEG system.

濃度を調節した PEG 及び擋汼子を入れ䚌挥しながら所 定時間置き、湿度センサーによって湿度を求め蒸気圧を 求めた。反応温度は $288 \mathrm{~K}$ であり、これは温度調節器で 制御したヒータ及び熱交換コイルによって温度制御を行 った水浴によって一定温度に保っている。また炭酸ナト リウム 1 水和塩の平衡蒸気圧の推算は Antoine 型蒸気圧 式を用いた。これによって求めた蒸気圧曲線を Fig.2 に 示す。 $288 \mathrm{~K}$ で蒸気圧が等しくなるのは、水分濃度が約 $25 \%$ のさであり望ましい吸水領域は水分濃度 $25 \%$ 以 上のときである。

連絡先 : 松村幸彦 matumura@mec.hiroshima-u.ac.jp

I. HIROSHIMA UNIVERSTTY 


\section{3. 反店速度}

\section{1 反応速度実験}

実験装置を Fig. 3 に示す。反応器は三角フラスコであ り、ここにスラリー及び擋汼子を入れ、擋汼しながら水分 濃度を調節して水和反応を進行させた。反応温度は温度 調節器で制御したヒ一タ及び熱交換コイルによって温度 制御を行った水浴によって一定温度に保っている。

\section{2 前処理}

今回用いた炭酸ナトリウム 1 水和塩は、粒子径 $355 \mu \mathrm{m}$ 程度の炭酸ナトリウム 10 水和塩を PEG $35 \mathrm{~g}$ 中で $30^{\circ} \mathrm{C}$ に 保ち 360 分間再生させたものを使用している。この時の 粒子径は再生と共に微粉化が進み特定できないが、既往 の研究 ${ }^{2)}$ では粒子径 $150 \mu \mathrm{m}$ を中心とした粒度分布となる ことが示されている。

\section{3 実験手順}

10 水和塩を再生させた状態にあるスラリーを $15^{\circ} \mathrm{C} に$ 保ち、所定時間置いたのちサンプリングした。その後所 定の量の水を加えて水濃度を調整する。その直後からサ ンプリングを行い、液相水濃度の経時変化を測定した。 このとき、スラリーをサンプリングした後に迅速に滤過 し、その濾液を Karl-Fischer 水分計で含有水分量を分析 することによって測定した。実験条件を Table 2 に示す。

\section{4 反応速度解析}

3.3 で得た実駼結果より反応速度解析を行った。これは 反応速度式を以下の(1)式のように仮定して、Excel のソ ルバーで実験值とフィッティングを行い反応速度定数を 決定した。ここでXは固体の反応率であり、再生した炭 酸ナトリウム 1 水塩の反応率は最初 0 であり、その後吸 水につれて上がっていき、これ以上吸えなくなったとき を 1 とする。

$$
\frac{d C}{d t}=-k\left(C-C_{e}\right)(1-X) \cdots(1)
$$

\section{5 結果及び考察}

Fig.4 に実験結果を示す。 $0 \mathrm{~min}$ のときに水を加えたこ とによって水分濃度が上昇したのち、再生してできた炭 酸ナトリウム 1 水和塩によって吸水が行われることによ って、徐々に水分濃度が低下していることが分かる。ま たその求まった実験より求めた結果と比較し、誤差が少 なくなるような反応速度定数 $\mathrm{k}$ を求めた結果 $\mathrm{k}=$ $0.0080 s^{-1}$ と求まった。

\section{4. 結言}

PEG-水系の平衡水蒸気圧を推算し、適切な吸湿条件を 設定した。推算結果に基づいた実験条件で実験を行い、 実際にスラリー中の水和反応を確認した。PEG 中での炭
酸ナトリウム 1 水和塩の吸水反応速度 $\mathrm{k}=0.008015 \mathrm{~s}^{-1}$ と求まった。

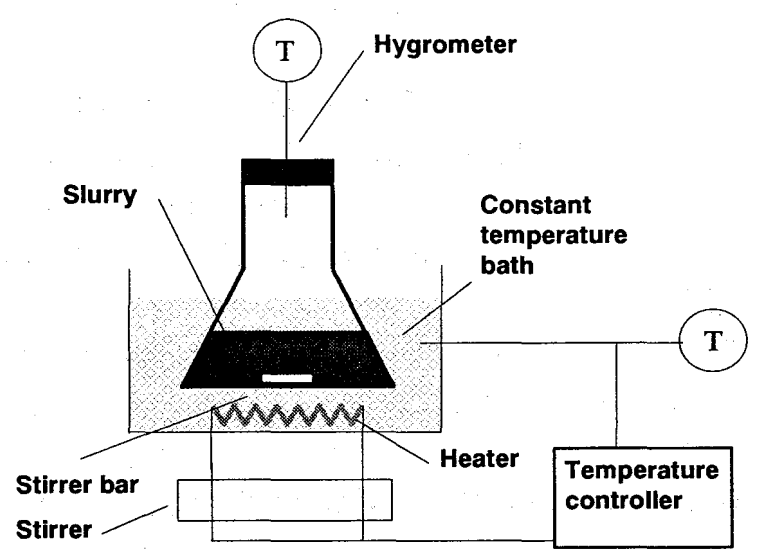

Fig.3 Experimental apparatus.

Table 2 Experimental conditions.

\begin{tabular}{lc}
\hline Temperature & $15^{\circ} \mathrm{C}$ \\
PEG & $35 \mathrm{~g}$ \\
Water addition & $5 \mathrm{~g}$ \\
$\mathrm{Na}_{2} \mathrm{CO}_{3} \cdot \mathrm{H}_{2} \mathrm{O}$ & $13.78 \mathrm{~g}$ \\
Total time & $300 \mathrm{~min}$ \\
Stirrer revolution speed & $300 \mathrm{rpm}$ \\
\hline
\end{tabular}

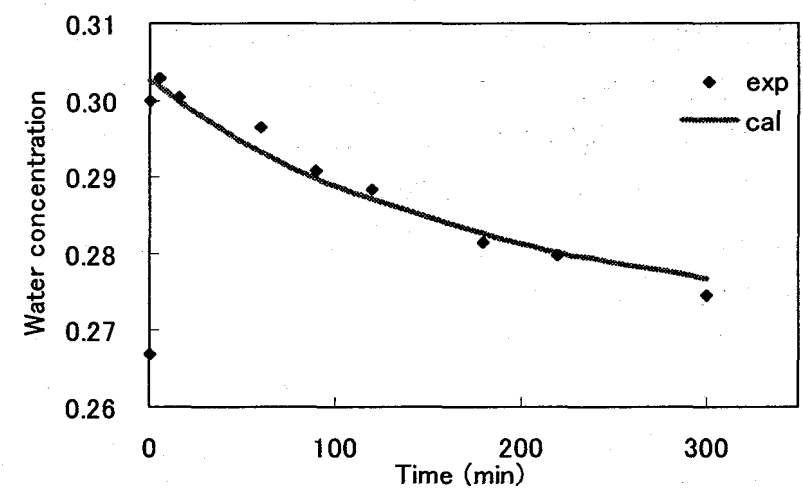

Fig.4 Variation in water concentration in liquid phase.

\section{〈参考文献〉}

1)岩田健三「ケミカル除湿システムにおける除湿剂の検 討」広島大学卒業論文(2003)

2)松村幸彦「冷熱蓄熱型および昇温型ケミカルヒートポ ンプにおける伝熱および反応特性」東京大学博士論文 (1993)

3)岩田健三「ケミカル調湿に用いる水和塩スラリーの吸 湿特性に関する基礎的検討」広島大学修士論文(2005) 